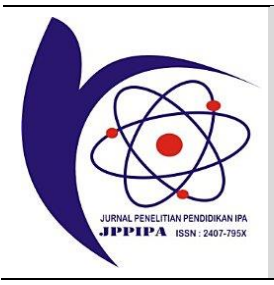

\title{
Application of Virtual Laboratory assisted Discovery Learning Model to Improve Science Process Skills and Learning Outcomes in Circulatory System Material
}

\author{
Misbahul Jannah ${ }^{1 *}$, Ibnu Khaldun², Safrida Safrida ${ }^{3}$ \\ ${ }^{1}$ Science Education Study Program, Postgraduate Program, Syiah Kuala University, Banda Aceh, Indonesia \\ ${ }^{2}$ Chemical Education Study Program, FKIP Syiah Kuala University, Banda Aceh, Indonesia \\ ${ }^{3}$ Biology Education Study Program, FKIP Syiah Kuala University, Banda Aceh, Indonesia
}

DOI: $10.29303 /$ jppipa.v7i1.470

\section{Article Info}

Received : August 28, 2020

Revised : September $28^{\text {th }}, 2020$

Accepted: December 12th 2020

\begin{abstract}
Discovery learning (DL) model is a learning model that hones students' process skills in finding concepts. Science process skills are needed to support optimal learning outcomes. The absence of a laboratory is thought to be the cause of the less optimal learning process so that supporting media such as virtual laboratories (VL) are needed. This study aims to determine the effect of implementing the VL-assisted DL model to improve Science Process Skills (SPS) and student learning outcomes in the circulatory system material. The research design used was the pretest-posttest control group design. The study population was all students of class VIII Junior High School Darul Ihsan Aceh Besar, and the sample selection was using random sampling techniques so that 60 students were selected as the research sample who were divided into two classes. The results showed that the application of the VL-assisted DL model in the experimental class experienced an increase in SPS by 71.05 (high category) compared to the control class. The application of the VL-assisted DL model also experienced an increase in learning outcomes, namely 73.16 (high category). The conclusion in this study is the application of the VL-assisted DL model to the circulatory system material has an effect on improving SPS and learning outcomes.
\end{abstract}

Keywords: Discovery Learning; Virtual Laboratory; Science Process Skills, Learning Outcomes

Citation: Jannah, M., Khaldun, I., Safrida, S., \& Muhibbuddin, M. (2020). Application of Virtual Laboratory assisted Discovery Learning Model to Improve Science Process Skills and Learning Outcomes in Circulatory System Material. Jurnal Penelitian Pendidikan IPA, 7(1), 34-40. doi:https://doi.org/10.29303/ippipa.v7i1.470

\section{Introduction}

The problem that occurs today is the results of student learning assessments are still not satisfactory. This is evidenced by the UN score on science learning in Aceh Besar from 2016 to 2019, namely 56.33; 40.47; 38,75 and 38,43 (Puspendik, 2016; Puspendik, 2017; Puspendik 2018; Puspendik 2019). The average UH score obtained by students is 42.8 and it has not yet reached the predetermined KKM, which is 65 . Based on this, it can be concluded that the results of learning science in Aceh Besar are still low. Learning Outcomes are an indicator to determine the success or failure of students in teaching and learning activities that have been carried out (Hartina et al., 2020). The learning resources used are only textbooks so that they do not yet support student activeness in discovery-based learning. The absence of a laboratory is thought to be an obstacle to the development of students' science process skills (SPS). SPS is a special skill that can simplify the way of learning 
science starting with observation, determining problems, and making conclusions (Pradana et al., 2020). SPS is one of the skills that students must have, where this skill requires students to understand, develop, and empower their learning process (Mahdian et al., 2019). One of the science materials whose level of mastery has not reached $55 \%$ is the circulatory system. The characteristics of this topic are abstract, which includes microscopic objects, organs, and processes that cannot be seen directly by students (Fajar, 2016). So far, the topic of the circulatory system has never been put into practice so that student SPS still needs to be explored and developed.

VL is a practicum simulation of the results of a visual representation of real traditional laboratory objects to confirm the results of the practicum and the theory being studied (Potkonjak et al., 2016). VL can also be defined as ICT-based learning that is able to develop learning using the practical method (Hidayati and Masril, 2019). VL-assisted learning can minimize rote learning and the process that takes place also becomes meaningful learning (Falode, 2018). According to Burkett and Smith (2016), the use of virtual in the experimental class group has been shown to have a positive effect on students both in terms of achievement and attitude when compared to traditional teaching methods.

The use of VL media will be more optimal if it is supported by a learning model that is able to facilitate the realization of meaningful learning for students. The model that can be used is the discovery learning (DL) learning model. This is supported by the statement of Ertikanto et al., (2018) that the DL model can improve student learning outcomes, can improve reasoning and the ability to think freely, and have skills in finding a concept. Asmara and Afriansyah (2018) also add that the DL model can provide opportunities for students to develop skills in carrying out the learning process independently and the teacher as the facilitator. In addition, Toy et al., (2018) argued that learning using the DL model not only saw the final result but also saw how the students' process of finding concepts. Apriani et al., (2020) revealed that the application of the DL model combined with VL can be a good alternative in improving the learning process because the combination of the two is able to provide feedback in helping students understand the concept and be able to motivate them to make improvements.

\section{Method}

This research uses applied research with experimental methods. The research design used was the pretest-posttest control group design. The sample was determined based on the random sampling technique, namely by giving a pretest to all VIII classes and then determining the two classes which had a homogeneous average value to be sampled. The classes selected to be the sample were class VIII-E with 30 students as the control class and VIII-G totaling 30 people as the experimental class at Junior High School Insan Qurani Aceh Besar.

\section{Result and Discussion}

\section{Instrument Validation Results}

The results of the Lesson Plan validation that have been carried out show that the average value is 0.75 and is classified as the valid category, while the average value of reliability is 89.4 and is classified as reliable. Meanwhile, the average results of the validation value of the SPS observation sheet are also classified as valid and reliable, namely 0.79 and 90.8 .

The worksheets and media validation process is carried out using an assessment sheet which consists of items covering the aspects of the feasibility of content, presentation, and grammar. The results of the worksheets validation showed the average score of the validity and reliability of the worksheets, namely 0.83 and 93.4. Both of these assessments are categorized as very valid and reliable. The assessment of media instruments is also classified as valid and reliable, namely 0.97 and 98.1. These results indicate that the validated media are valid and reliable.

The process of question validation is carried out in two ways, namely validation by experts and testing of questions to students. The test instrument in this study consisted of 38 item questions. The results of validation by experts were calculated using the Aiken's V formula. Of the 38 items, 26 items had a valid score between 0.75 1.00 which was categorized as valid while the other 12 items did not reach the critical point of the Aiken's index with a score of 0.50 so that categorized as invalid. A valid question means that the item has good content validity and supports the overall test. The question is invalid because there are several items that have indicators and cognitive levels that are not appropriate.

The questions were also tested in 2 classes, namely IX C and IX D Junior High School Darul Ihsan. The trial was conducted to determine the distinguishing power, level of difficulty, and reliability of the questions used. The number of questions tested was 38 items and then analyzed with the test proanal developed by Khaldun (2017). The trial results showed that of the 38 items tested, 27 were suitable for use, while the other 11 items were not suitable because they had different power, difficulty level, low reliability and validity. 


\section{Results of Science Process Skills}

The data from the SPS analysis were first tested for normality and homogeneity and then analyzed the increase in SPS using the t-test and N-gain. Analysis of the initial SPS ability in the control and experimental classes can be seen in Table 1

Table 1. Average Pre-SPS Value in the Experiment and Control Class

\begin{tabular}{lllll}
\hline Class & $\begin{array}{l}\text { Ave- } \\
\text { rage }\end{array}$ & $\begin{array}{l}\text { Norma- } \\
\text { lity }\end{array}$ & $\begin{array}{l}\text { Homoge- } \\
\text { neity }\end{array}$ & Sig. \\
\hline $\begin{array}{l}\text { Experi- } \\
\text { ment }\end{array}$ & 36.86 & $\begin{array}{l}\text { Normal } \\
\text { Sig: } 0.069\end{array}$ & $\begin{array}{l}\text { Homoge- } \\
\text { neous }\end{array}$ & $\begin{array}{l}\text { Not significant } \\
\text { Sig (2-tailed) }\end{array}$ \\
Control & 37.42 & $\begin{array}{l}\text { Normal } \\
\text { Sig: } 0.091\end{array}$ & sig: 0.921 & $0.769>0.025$ \\
& & & \\
\hline
\end{tabular}

Based on Table 1, it is obtained that the pre-SPS average score data in the experimental class is 36.86 and the control class is 37.42 which indicates that the abilities of the two classes are still low. The results of the normality test for the experimental class were 0.069> 0.05 and the control class was $0.091>0.05$, which means that the data were normally distributed. The homogeneity test result between the two classes was $0.921>0.05$, which means the data was homogeneous. The $\mathrm{t}$-test result shows that the sig value is $0.769>0.025$. This shows that there is no significant difference between the pre-SPS control class and the experimental class, which means that the students' initial abilities in the experimental and control classes are the same. Meanwhile, the results of post-SPS data analysis for the control and experimental classes can be seen in Table 2 .

Table 2. Average Value of Post SPS in Experiment and Control Class

\begin{tabular}{|c|c|c|c|c|}
\hline Class & $\begin{array}{l}\text { Avera } \\
\text { ge }\end{array}$ & $\begin{array}{l}\text { Normalit } \\
y\end{array}$ & $\begin{array}{l}\text { Homoge } \\
\text { neity }\end{array}$ & Sig. \\
\hline $\begin{array}{l}\text { Experi- } \\
\text { ment }\end{array}$ & 66.95 & $\begin{array}{l}\text { Normal, } \\
\text { Sig: } 0.823\end{array}$ & $\begin{array}{l}\text { Homoge- } \\
\text { neous }\end{array}$ & $\begin{array}{l}\text { Significant } \\
\text { Sig (2-tailed) }\end{array}$ \\
\hline Control & 46.20 & $\begin{array}{l}\text { Normal, } \\
\text { Sig: } 0.778\end{array}$ & sig: 0.277 & $0.000<0.025$ \\
\hline
\end{tabular}

The results of the analysis in Table 2. indicate that the post-SPS average score for the experimental class was 66.95 and the control class was 46.20 . The results of the test for normality and homogeneity of the experimental and control classes show that the data is normally distributed and homogeneous because it has a sig value $>0.05$. The results of the t-test show that the sig value is $0.026<0.05$, which means that the data has a significant difference between the control class and the experimental class.

The students' SPS score in this study was seen before and after the treatment which aims to determine the improvement that occurs during the learning process in the control and experimental classes. The difference in the average ability of students can be seen in Figure 1.

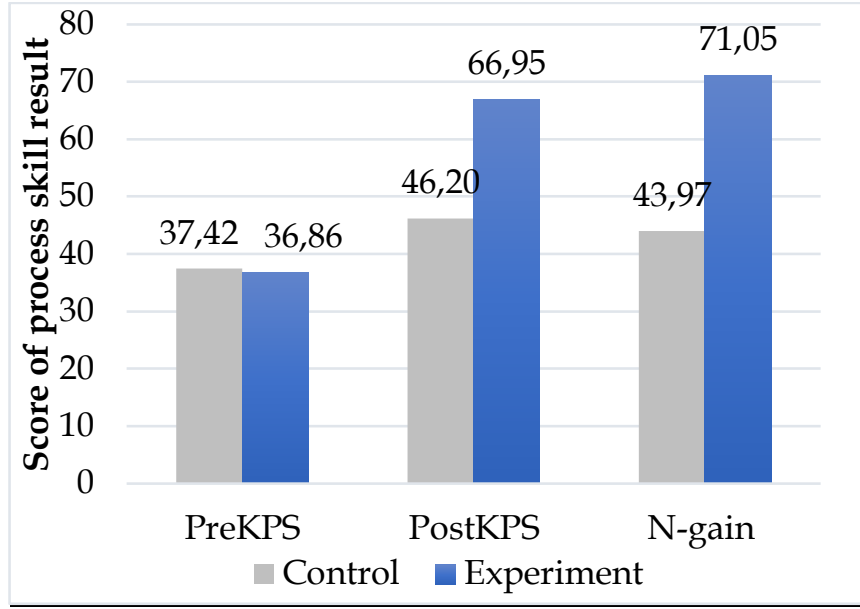

Figure 1. Improved student SPS

Based on Figure 1, it can be seen that the SPS average score before being given treatment in the control and experimental classes was 37.42 and 38.86 , the results of both were classified as sufficient while the average SPS score of students after treatment had increased. The average percentage of SPS in the control class has increased from 43.88 (Enough) to 57.38, while the results of the SPS mean score assessment in the experimental class from 46.20 to 66.95 . The amount of increase in SPS in this study is measured using the $\mathrm{N}$-gain. The results of the student's SPS N-gain test analysis can be seen in Table 3.

Table 3. Results of SPS N-gain Average Difference Test in Experiment and Control Class

\begin{tabular}{lllll}
\hline Class & $\begin{array}{l}\text { Avera } \\
\text { ge }\end{array}$ & $\begin{array}{l}\text { Norma- } \\
\text { lity }\end{array}$ & $\begin{array}{l}\text { Homoge- } \\
\text { neity }\end{array}$ & Sig. \\
\hline Experi- & 71.05 & Normal & Homoge & Significant \\
ment & & Sig: 0.298 & $\begin{array}{l}\text { neous } \\
\text { Sig (2-tailed) }\end{array}$ \\
Control & 43.97 & $\begin{array}{l}\text { Normal } \\
\text { Sig: } 0.202\end{array}$ & sig: 0.403 & $0.000<0.025$ \\
& & Sig: 000 & \\
\hline
\end{tabular}

Based on Table 3, it can be seen that the results of the different tests in the average $\mathrm{N}$-gain value in the control class are 43.93 (moderate category) and the experimental class is 71.05 (high category). The results of the N-gain normality and homogeneity test showed that the data were normally distributed and homogeneous. Meanwhile, the t-test results show that the sig value is $0.000<0.025$, which means that there is a significant difference between the control class and the experimental class.

The real difference between the control class and the experimental class can be seen from the high increase in the average $\mathrm{N}$-gain value of the experimental class compared to the control class. The increase in SPS that occurs in the experimental class is due to the application of the VL-assisted DL model in the learning process. The application of this model is able to direct students to be actively involved, can improve performance in 
practicing virtually, increase scientific literacy, and develop an understanding of a concept through assigning certain tasks to students based on the SPS indicators to be achieved.

Student SPS test results improved and got better after being given the posttest because practicum activities were carried out in learning with the help of VL. Students' skills can be trained with several attempts, one of which is practicum activities, either directly or virtually. Ismail., Et al (2016) stated that students' abilities can be developed through VL because VL can be used as a set of computer programs that can simulate laboratory activities like real experiments. Learning activities that make use of VL are equipped with equipment and materials such as those used in real experiments so that they make it easy for students to carry out practicum activities.

The results showed that the application of the DL model with the help of VL in the experimental class could have a great influence on students' science process skills. The score of science process skills in the experimental class taught by applying the VL-assisted DL model was higher than the control class. The results of this study support previous research conducted by Yusuf and Widyaningsih (2018) showing that the use of VL has a very good impact on students' science process skills.

SPS indicators that are measured during the learning process, namely the ability of students to make reasonable guesses in formulating hypotheses, planning experiments to be designed, conducting pre-planned experiments, observing what happens, interpreting data based on the results obtained, predicting possible appropriate answers with the aim of then linking it to the concept and the last is communicating the results both orally and in writing. An increase in the SPS indicator can be seen in Table 4 .

Table 4. Comparison of the SPS N-gain value on each indicator

\begin{tabular}{lll}
\hline Aspect & Control & Experiment \\
\hline Formulate a hypothesis & 24 & 63 \\
Planning Experiments & 20 & 65 \\
Do an experiment & 18 & 73 \\
Observe & 100 & 100 \\
Interpret & 51 & 72 \\
Predict & 49 & 63 \\
Apply the concept & 45 & 67 \\
Communicate & 52 & 67 \\
\hline
\end{tabular}

Based on Table 4, the results of the SPS value recapitulation show that there is a difference in the average $\mathrm{N}$-gain value in the control and experimental classes. The experimental class whose learning process uses the VL-assisted DL model gets a high score compared to the control class in every aspect of the SPS that is assessed. The score of the process value on the indicators of formulating hypotheses, planning and conducting experiments in the control class has increased very little compared to the experimental class. The low value increase in the three indicators is caused by the absence of a place for students to propose hypotheses, plan experiments and conduct experiments so that students' skills are not tested properly, meanwhile in the experimental class the results obtained are quite good because of the VL-assisted DL model. The application of the DL model makes students able to formulate provisional assumptions to be verified through experiments with the help of VL. The use of VL is also very useful for increasing student enthusiasm for learning through interactivity and providing a platform for students to be able to plan experiments.

Skill scores on the indicators of conducting experiments and interpreting have increased in the experimental class with the high category. The increase in the skills of conducting the experiment is because with the use of VL students are able to carry out experimental procedures according to the planning that has been made. Students are also able to combine information based on a theory with experimental results and be able to analyze results to look for patterns of relationships between the two. Indicators of predicting, applying concepts, and communicating also have a fairly good increase, although not much different from the control class. This increase occurred because students were able to find a relationship between experimental data and theory so that a conclusion was obtained which was reported in the form of a systematic report by students. This is in accordance with the statement of Lidiana., Et al. (2018) which states that finding the concept of knowledge through the DL model can make it easier for students to understand the concept.

The SPS aspect that received the highest score was the observation process. The high level of observing indicators is due to the direct observation process so that students use their sensory devices to observe carefully and pay attention to the supporting variables contained in the experiment. As stated by Maharani and Hardini (2017) that a concept obtained from the results of one's own thinking and creativity is more meaningful and more durable than a gift from the teacher.

Overall there was an increase in SPS in both classes, but the increase in SPS in the experimental class was higher than in the control class. These results are supported by research by Nelyza et al., (2015) which states that DL learning can improve student SPS by $62.24 \%$. This can happen because during the learning process students are taught to find their own knowledge from the results of discussions and experiments. 
Students are able to classify the information obtained and used to interpret a material. Supriyadi and Kurniawati (2017) say that the use of VL in the learning process has a very big impact, namely, it can provide new experiences to students to present problems, make hypotheses, design experiments, analyze data and make conclusions in the middle of school conditions that do not allow practicum. real. Ilmi, et al (2020) also argued that the use of images or teaching materials that support observations such as VL in circulatory system material can make abstract sub-topics in material more concrete and easy for students to understand.

\section{Student learning outcomes}

Analysis of learning outcomes can be seen from the acquisition of pretest and posttest scores that have been given to students. Analysis of the initial ability of student learning outcomes can be seen in Table 4 .

Table 5. The Average Pretest Value of Student Learning Outcomes in the Experiment and Control Class

\begin{tabular}{|c|c|c|c|c|}
\hline Class & $\begin{array}{l}\text { Avera } \\
\text { ge }\end{array}$ & $\begin{array}{l}\text { Norma- } \\
\text { lity }\end{array}$ & $\begin{array}{l}\text { Homoge- } \\
\text { neity }\end{array}$ & Sig \\
\hline $\begin{array}{l}\text { Experi- } \\
\text { ment }\end{array}$ & 37.50 & $\begin{array}{l}\text { Normal } \\
\text { Sig: } 0.059\end{array}$ & $\begin{array}{l}\text { Homoge- } \\
\text { neous }\end{array}$ & $\begin{array}{l}\text { Not significant } \\
\text { Sig (2-tailed) }\end{array}$ \\
\hline Control & 38.17 & $\begin{array}{l}\text { Normal } \\
\text { Sig: } 0.362\end{array}$ & sig: 0.076 & $0.797>0.025$ \\
\hline
\end{tabular}

The results of the analysis in table 4 . show that the pretest mean score of the experimental class was 37.50 and the control class was 38.17. This shows that the initial ability of students in both classes is still low. The normality test shows that the data is normally distributed, namely $0.059>0.05$ in the experimental class and $0.362>0.05$ in the control class. Meanwhile, the homogeneity test showed that the two classes had homogeneous data acquisition with an insignificant $t$ test value, namely $0.797>0.025$. The insignificance of the t-test value indicates that there is no significant difference between the control and experimental class pretest. The results of the analysis of the posttest mean value of student learning outcomes can be seen in Table 6.

Table 6. Average Prosttest Value of Student Learning Outcomes in the Experiment and Control Class

\begin{tabular}{|c|c|c|c|c|}
\hline Class & $\begin{array}{l}\text { Avera } \\
\text { ge }\end{array}$ & $\begin{array}{l}\text { Norma- } \\
\text { lity }\end{array}$ & $\begin{array}{l}\text { Homoge- } \\
\text { neity }\end{array}$ & Sig \\
\hline $\begin{array}{l}\text { Experi- } \\
\text { ment }\end{array}$ & 83.33 & $\begin{array}{l}\text { Normal } \\
\text { Sig: } 0.129\end{array}$ & $\begin{array}{l}\text { Homoge- } \\
\text { neous }\end{array}$ & $\begin{array}{l}\text { Significant } \\
\text { Sig (2-tailed) }\end{array}$ \\
\hline Control & 72.00 & $\begin{array}{l}\text { Normal } \\
\text { Sig: } 0.184\end{array}$ & sig: 0.598 & $0.000<0.025$ \\
\hline
\end{tabular}

Based on Table 6, it can be seen that the two classes are normally distributed, namely $0.19>0.05$ in the experimental class and $0.184>0.05$ in the control class. Apart from being normally distributed, the data for the two classes were also homogeneous, namely 0.598>0.05.
The results of the t-test analysis show that the sig value is $0,000<0.025$, which means that the data shows a significant difference between the control class and the experimental class. The increase in the posttest average score in the experimental class was included in the high category, namely 83.33, and in the control class, namely 72.00 .

The acquisition shows that the average score of students' prior knowledge on circulatory system material is still low. After learning is done, there is an increase in the Posttest score. The comparison of the average score for the increase in the pretest, posttest, and $\mathrm{N}$-gain scores can be seen in Figure 2.

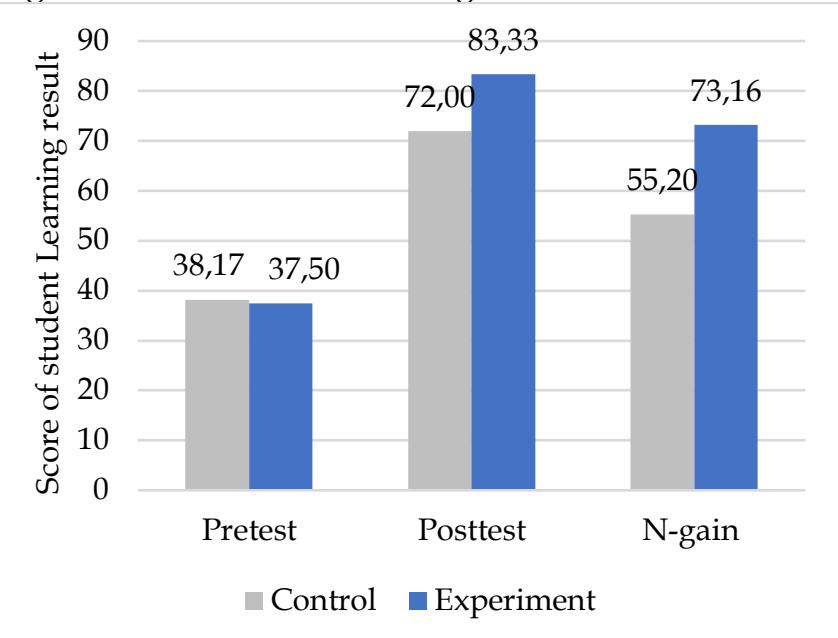

Figure 2. Improved student learning outcomes

Based on the average score, it can be concluded that the two classes experienced an increase in knowledge, but the experimental class had a greater increase than the control class. The amount of increase can be seen from the $\mathrm{N}$-gain value of the two classes. The analysis of the $\mathrm{N}$-gain value for increasing student learning outcomes can be seen in Table 7 .

Table 7. Results of the N-gain Mean Difference Test for Student Learning Outcomes in the Experiment and Control Class

\begin{tabular}{lllll}
\hline Class & $\begin{array}{l}\text { Avera } \\
\text { ge }\end{array}$ & $\begin{array}{l}\text { Norma- } \\
\text { lity }\end{array}$ & $\begin{array}{l}\text { Homoge- } \\
\text { neity }\end{array}$ & Sig \\
\hline Experi & 73.16 & $\begin{array}{l}\text { Normal } \\
\text { ment }\end{array}$ & $\begin{array}{l}\text { Homoge- } \\
\text { neous }\end{array}$ & $\begin{array}{l}\text { Significant } \\
\text { Sig }(2 \text {-tailed })\end{array}$ \\
Control & 55.20 & $\begin{array}{l}\text { Sig: } 0.070 \\
\text { Normal } \\
\text { Sig: } 0.792\end{array}$ & sig: 0.139 & $0.000<0.025$ \\
& & & \\
\hline
\end{tabular}

The results of the analysis of the normality test show that the $\mathrm{N}$-gain data for student learning outcomes are normally distributed, namely $0.070>0.05$ in the experimental class and $0.792>0.05$ in the control class. Both classes have a homogeneous data distribution, namely $0.139>0.05$. The results of the t-test analysis on the N-gain data indicate that there is a significant 
difference between the experimental class and the control class, namely with a sig value of $0.000<0.025$.

The difference in learning outcomes between the two classes can be seen from the mean number of each indicator in the control and experimental classes. The average score of learning outcomes for each indicator can be seen in Table 8 .

Table 8. Results Comparison of the N-gain value of learning outcomes on each indicator

\begin{tabular}{lll}
\hline Indicator & Control & Experiment \\
\hline 3.7.1 Identify blood function & 82 & 57 \\
3.7.2 To identify the characteristics and functions of the constituent components of blood & 50 & 64 \\
3.7.3 Describes the blood clotting process & 59 & 80 \\
3.7.4 Describe the characteristics of blood groups A, B, AB, and O & 33 & 82 \\
3.7.5 Identify the characteristics of the heart and blood vessels & 40 & 79 \\
3.7.6 Identify the difference between arteries and veins & 51 & 75 \\
3.7.7 Describes the circulatory process in humans & 69 & 59 \\
3.7.8 Identify factors that affect the heart rate & 52 & 74 \\
3.7.9 Describe abnormalities in the circulatory system and preventive measures & 76 \\
\hline
\end{tabular}

Based on Table 8, the increase in the control class occurs in indicator 3.7.1, which is identifying blood function. This indicator contains theories about the various functions of blood in the human body. Indicator 3.7.1 is only in the form of memorizing concepts that students can understand without having to have a practicum. Whereas in the experimental class the highest increase in the indicator is in indicator 3.7.4, which describes the characteristics of blood groups $\mathrm{A}, \mathrm{B}, \mathrm{AB}$ and O. Indicator 3.7.4 contains various kinds of characteristics of blood groups and how to distinguish them. This material requires practicum such as checking blood groups so that students can differentiate or classify blood groups according to their characteristics. In general, the increase in student learning outcomes in the experimental class is higher than the control class because there is an opportunity given to students through the DL model to analyze their own knowledge while doing practicum activities virtually.

The increase in learning outcomes that occurs proves that the learning process using the VL-assisted DL model can make student learning outcomes better. This statement is in accordance with the opinion of Sari et al. (2016) which states that the VL-assisted DL model can improve students' mastery of concepts because students can visualize an experiment or concept more interactively and will have an impact on their learning outcomes. Learning with the DL model can make students better understand and understand the material being taught. This is due to a series of information or data obtained by students directly through experiments and observations (Maharani and Hardini, 2017). Through experiments and observations, students can find, investigate, and analyze a concept by themselves so that the results obtained are more durable and always be remembered.

Statements that support the improvement of learning outcomes due to the application of this model were expressed by Lidiana et al. (2018) said that the VL- assisted DL model can improve learning outcomes of the material being taught and students' analytical abilities because students are required to try to solve problems and seek their own knowledge through existing sources. Another opinion was also expressed by Adyan et al. (2019) by saying that the VL-assisted DL model can be an alternative to a real practicum that cannot be implemented in schools and this model helps students improve their cognitive abilities in explaining abstract material.

\section{Conclusion}

The application of the VL-assisted DL learning model to the circulatory system material has an effect on improving SPS and student learning outcomes.

\section{References}

Adyan, F.B., Purwanto, A., dan Nirwana. 2019. Upaya meningkatkan motivasi dan hasil belajar siswa dengan model discovery learning berbantuan virtual laboratory. Jurnal Kumparan Fisika, 2(3):153160. doi:https://doi.org/10.33369/jkf.2.3.153-160

Apriani, N.W.R., Doyan, A., Sridana, N., dan Susilawati. (2020). The validity of physical learning device based on discovery learning model assisted by a virtual laboratory. Jurnal Penelitian Pendidikan IPA, 6(2): doi:https:// doi.org/10.29303/ippipa.v6i2.264

Asmara, R dan Afriansyah, E.A. (2018). Perbedaan peningkatan kemampuan komunikasi matematis siswa antara model eliciting activities dan discovery learning. Suska Journal of Mathematics Education, $4(2)$, 77-87. doi:https://doi.org/10.24014/sjme.v4i2.5714 
Burkett, V.C dan Smith, C. (2016). Simulated vs handson laboratory position paper. Electronic Journal of Science Education, 20(9), 8-24.

Ertikanto., Rosidin, U., Distrik, I.W., Yuberti \& Rahayu, T. (2018). Comparison of mathematical representative skill and science learning result in class with problem-based and discovery learning model. Jurnal Pendidikan IPA Indonesia, 7(1), 106113. doi:https://doi.org/10.15294/jpii.v6i2.9512

Fajar, N. (2016). Proses pembelajaran biologi pada materi sistem peredaran darah manusia di kelas VIII SMP Negeri 3 Ambatan. Ta'dib, 19(2), 103-104. doi:https://doi.org/10.31958/jt.v19i2.466

Falode, O.C. (2018). Pre-service teachers' perceived ease of use, perceived usefulness, attitude, and intentions towards virtual laboratory package utilization in teaching and learning of physics. Malaysian Online Journal of Education Technology, 6(3), 63-72. doi:https://doi.org/10.17220/mojet.2018.03.005

Hartina, L., Rosidim, U., dan Suyatna, A. (2020). Pengaruh penerapan instrumen performance assessment pada pembelajaran IPA berbasis laboratorium real terhadap hasil belajar siswa. Jurnal Penelitian Pendidikan IPA, 6(1): 25-31. doi:https://doi.org/10.29303/jppipa.v6i1.299

Hidayati dan Masril. (2019). Penggunaan LKM untuk menunjang kegiatan laboratorium virtual fisika inti. Jurnal Penelitian Pendidikan IPA, 5(2): 149-153. doi:https:// doi.org/10.29303/jppipa.v5i2.250

Ilmi, R.H.N., Nurhayati, B dan Adnan. 2020. Pengembangan bahan ajar sistem peredaran darah berbasis electronic book terintegrasi dengan virtual labs untuk siswa kelas XI IPA SMA. Jurnal Biology Teaching and Learning, 3(1):1-14.

Khaldun, I. 2017. Proanaltes V6 Program Analisis Butir Soal dan Penilaian Hasil Belajar. Banda Acah: Jurusan Pendidikan Kimia Fakultas Keguruan dan Ilmu Pendidikan Universitas Syiah Kuala.

Lidiana, H., Gunawan dan Taufiq. M. 2018. Pengaruh Model discovery leaning berbantuan media Phet terhadap hasil belajar fisika peserta didik kelas IX SMAN 1 Kediri tahun ajaran 2017/2018. Jurnal Pendidikan Fisika dan Teknologi, 4(1):33-39. doi:https://doi.org/10.29303/ipft.v4i1.519

Mahdian, Almubarak dan Hikmah, N. (2019). Implementasi model pembelajaran ICARE (introductionconnect-apply-reflect-extend) terhadap keterampilan proses sains pada materi larutan elektrolit dan non elektrolit. Jurnal Penelitian Pendidikan IPA, 5(1): 92-97. doi:https://doi.org/10.29303/jppipa.v5i1.184

Maharani, B.Y dan Hardini, A.T.A. (2017). Penerapan model pembelajaran discovery learning berbantuan benda konkret untuk meningkatkan hasil belajar IPA. E-jurnal Mitra Pendidikan, 1(5), 549-561.

Nelyza, F., Hasan, M dan Musman,M. (2015). Implementasi model discovery learning pada materi laju reaksi untuk meningkatkan keterampilan proses sains dan sikap sosial peserta didik MAS Ulumul Quran Banda Aceh. Jurnal Pendidikan Sains Indonesia, 3(2), 14-21.

Potkonjak, V., Gardner, M., Callaghan, V., Mattila, P., Guetl, C., Petrovic, V.M dan Jovanonic. (2016). Virtual laboratories for education in science, technology, and engineering: A review. Computers and Education. 95, 309-327. doi:https://doi.org/10.1016/j.compedu.2016.02. $\underline{002}$

Pradana, D., Nur, M., dan Supratno, N. (2020). Improving critical thinking skill of junior high school students through science process skills based learning. Jurnal Penelitian Pendidikan IPA, $6(2)$,

166-172. doi:https://doi.org/10.29303/jppipa.v6i2.428

Puspendik. (2016). Laporan Hasil Ujian Nasional Tahun Pelajaran 2016-2019. Jakarta : Balitbang, Kemendikbud.

Sari, P.I., Gunawan dan Harjono, S. (2016). Penggunaan discovery learning berbantuan laboratorium virtual pada penguasaan konsep fisika siswa. Jurnal Pendidikan Fisika dan Teknologi, 2(4), 176-182. doi: https://doi.org/10.29303/jpft.v2i4.310

Toy, B.A.I., Karwud, F.F., Costa, J.F., Langkun, J.F dan Rondonuwu, F.S. (2018). Desain bahan ajar biologi berbasis discovery learning dengan scientific approach untuk materi jamur di kelas $\mathrm{X}$ SMA. BIOSFER: Jurnal Pendidikan Biologi, 11(1), 68-77. doi: https://doi.org/10.21009/biosferjpb.11-1 